\title{
Facile preparation of $\mathrm{Sn}-\boldsymbol{\beta}$ zeolites by post-synthesis (isomorphous substitution) method for isomerization of glucose to fructose
}

\author{
Min Liu a,*, Songyan Jia ${ }^{\mathrm{b}}$, Changzeng Li ${ }^{a}$, Anfeng Zhang a , Chunshan Song a,c,d, Xinwen Guo a,\# \\ a State Key Laboratory of Fine Chemicals, Department of Catalysis Chemistry and Engineering, School of Chemical Engineering, Dalian University of \\ Technology, Dalian 116012, Liaoning, China \\ b Dalian National Laboratory for Clean Energy, Dalian Institute of Chemical Physics, Chinese Academy of Sciences, Dalian 116023, Liaoning, China \\ c EMS Energy Institute, PSU-DUT Joint Center for Energy Research and Department of Energy \& Mineral Engineering, Pennsylvania State University, \\ University Park, Pennsylvania 16802, United States \\ d Department of Chemical Engineering, Pennsylvania State University, University Park, Pennsylvania 16802, United States
}

A R T I C L E I N F O

Article history:

Received 27 February 2014

Accepted 10 March 2014

Published 20 May 2014

\section{Keywords:}

Sn- $\beta$

Isomorphous substitution

Glucose

Isomerization

Fructose

\begin{abstract}
A B S T R A C T
Sn- $\beta$ zeolites were facilely synthesized by a post-synthesis method consisting of two steps, i.e., heteroatom removal and isomorphous substitution by reaction with $\mathrm{SnCl}_{4}$. This significantly shortened the Sn- $\beta$ zeolite preparation time from the previously reported $40 \mathrm{~d}$ to less than $1 \mathrm{~d}$. It was shown that Sn- $\beta$ samples prepared using the post-synthesis method had higher Sn contents than that prepared using a hydrothermal method. The as-synthesized Sn- $\beta$ zeolites were tested in the isomerization of glucose to fructose in aqueous media. The effects of reaction temperature, reaction time, catalyst amount, solvent, and halide additive on the isomerization reaction over Sn-Al- $\beta$ zeolites were studied in detail. Under the optimized conditions, the yield of fructose reached a maximum of $\sim 43 \%$. The catalysts can be reused without loss of activity after regeneration by calcination.
\end{abstract}

(C) 2014, Dalian Institute of Chemical Physics, Chinese Academy of Sciences. Published by Elsevier B.V. All rights reserved.

\section{Introduction}

The use of alternative energy sources is attracting increasing attention, because of the current high consumption of fossil resources and concomitant serious environmental problems [1]. Biomass is considered a promising feedstock for the production of biobased chemicals due to its renewable and carbon-neutral properties [1]. Some progress in the catalytic conversion of saccharides to valuable chemicals such as 5-hydroxymethylfurfural (HMF) has been achieved [2-4]. HMF, which is a versatile chemical intermediate, can be easily obtained by dehydration of fructose in acid-catalyzed systems [5-7]. However, the natural abundance of fructose is low, so the production cost of fructose-based HMF is high. Glucose is the most abundant and widespread monosaccharide, and could be a good candidate as a source of HMF [8]. However, the efficient conversion of glucose to HMF remained a challenge until Zhao et al. [6] reported that $\mathrm{CrCl}_{3}$ could catalytically convert glucose to HMF in an ionic liquid. The direct conversion of glucose to HMF consists of two steps: the isomerization of glucose to fructose and the dehydration of fructose to HMF $[9,10]$. The critical issue is how to achieve effective glucose isomerization to fructose in suitable reaction media.

Typical approaches for isomerizing glucose include basecatalyzed and enzymatic techniques. For base-catalyzed isomerization, excess homogeneous inorganic bases in aqueous

\footnotetext{
* Corresponding author. Tel/Fax: +86-411-84986134; E-mail: lium@dlut.edu.cn

\# Corresponding author. Tel: +86-411-84986133; Fax: +86-411-84986134; E-mail: guoxw@dlut.edu.cn This work was supported by the National Natural Science Foundation of China $(20803005,21306186)$. DOI: 10.1016/S1872-2067(14)60071-1 | http://www.sciencedirect.com/science/journal/18722067 | Chin. J. Catal., Vol. 35, No. 5, May 2014
} 
solution are generally used, but fructose has very poor stability in strongly basic systems $[11,12]$. Although enzymatic isomerization can effectively produce fructose, it is sensitive to operating conditions, such as $\mathrm{pH}$, temperature, and feedstock purity, and requires a long treatment time.

Sn- $\beta$ zeolites, which are Lewis acids and potential heterogeneous catalysts, are used in a number of reactions such as Baeyer-Villiger oxidation of cyclic ketones [13], the cyclization of citronellal to isopulegol (cyclic carbonylene reaction) [14], and Meerwein-Ponndorf-Verley-Oppenauer redox reactions [15]. Recently, Moliner et al. [16] effectively isomerized glucose to fructose over Sn- $\beta$ zeolites in aqueous media, and Sn- $\beta$ zeolites have also been used in the isomerization of xylose and the one-pot synthesis of HMF or 5-(ethoxymethyl)furfural from glucose $[10,17,18]$. However, the preparation of $\mathrm{Sn}-\beta$ zeolites by traditional hydrothermal methods is unacceptably long, generally requiring about $40 \mathrm{~d}$ to achieve full crystallization. Chang et al. [17] recently reported a rapid synthesis of Sn- $\beta$ zeolites using a modified seeding method, but it still required about $2 \mathrm{~d}$. More importantly, all of the above synthesis procedures cause environmental pollution, e.g., by fluorides $[13,17-19]$. It is therefore desirable to find eco-friendly and rapid ways of preparing $\mathrm{Sn}-\beta$ zeolites. Post-synthesis (isomorphous substitution) through a solid-gas reaction of highly siliceous zeolites with metal chloride vapors can implant quantities of metal atoms into the zeolite framework. Because the siliceous zeolite precursors have already been crystallized, post-synthesis avoids the need for crystallization of the Sn- $\beta$ zeolites, as reported in the literature [10,13,16-18], substantially reducing the synthesis time. Isomorphous substitution methods for preparing $\mathrm{Sn}-\beta$ zeolites may have advantages in terms of commercialization and environmental protection.

In this paper, we report the facile preparation of Sn- $\beta$ zeolites through isomorphous substitution of dealuminated/deboronated zeolites with $\mathrm{SnCl}_{4}$ vapor, and use of these zeolites to catalyze isomerization of glucose to fructose in aqueous media.

\section{Experimental}

\subsection{Materials}

Anhydrous $\mathrm{SnCl}_{4}$ (AR) was purchased from Sinopharm (China), glucose monohydrate (AR) was purchased from Tianjin Kermel (China), and $\mathrm{HNO}_{3}$ (65\%, AR) was purchased from Beijing Chemical Plant. Al- $\beta$ zeolite was obtained from the Shenyang University of Chemical Technology (China). B- $\beta$ zeolite was obtained from Dalian University of Technology. Deionized water was supplied by Dalian University of Technology. All chemicals were used as received, without further purification.

\subsection{Catalyst synthesis}

The Sn-Al- $\beta$ catalysts (prepared using Al- $\beta$ zeolite as the precursor) were prepared using a previously reported postsynthesis method [13]. The preparation involved dealumination and isomorphous substitution with $\mathrm{SnCl}_{4}$ vapor. The Al- $\beta$ zeolite (H-form, $\mathrm{Si} / \mathrm{Al}$ atomic ratio 15 ) was treated in $4 \mathrm{~mol} / \mathrm{L}$
$\mathrm{HNO}_{3}$ at $348 \mathrm{~K}$ for $2 \mathrm{~h}$, with a solid/liquid ratio of $1 \mathrm{~g} / 10 \mathrm{~mL}$, followed by drying at $393 \mathrm{~K}$ for $2 \mathrm{~h}$ and calcination in air at 813 $\mathrm{K}$ for $5 \mathrm{~h}$, resulting in a highly siliceous zeolite ( $\mathrm{Si} / \mathrm{Al}$ atomic ratio 221:1). In the isomorphous substitution, the dealuminated $\beta$ zeolite was pretreated in a quartz tubular reactor at $813 \mathrm{~K}$ for $2 \mathrm{~h}$ under a $\mathrm{N}_{2}$ flow. Then the $\mathrm{N}_{2}$ flow was diverted to an anhydrous $\mathrm{SnCl}_{4}$ liquid in a glass bubbler and the $\mathrm{SnCl}_{4}$ vapor was carried by the $\mathrm{N}_{2}$ flow to contact the sample bed for a defined time. After the treatment, the sample was purged with pure $\mathrm{N}_{2}$ at $813 \mathrm{~K}$ for $2 \mathrm{~h}$ to remove any residual $\mathrm{SnCl}_{4}$ from the sample powder. After cooling to room temperature under $\mathrm{N}_{2}$, the treated sample was washed three times with ethanol and then dried in air at $373 \mathrm{~K}$ overnight. Finally, the sample was calcined at $813 \mathrm{~K}$ for $4 \mathrm{~h}$.

Sn-B- $\beta$ catalysts (synthesized using B- $\beta$ zeolite as the precursor) were prepared using a post-synthesis method reported in the literature [20]. B- $\beta$ zeolite ( $\mathrm{Si} / \mathrm{B}$ atomic ratio 11 ) was treated in $1 \mathrm{~mol} / \mathrm{L} \mathrm{HCl}$ at $333 \mathrm{~K}$ for $2 \mathrm{~h}$, with a solid/liquid ratio of $1 \mathrm{~g} / 10 \mathrm{~mL}$, resulting in a highly siliceous zeolite (Si/B atomic ratio 793:1). The isomorphous substitution process was the same as that for the Al- $\beta$ zeolite.

For comparison experiments, an $\mathrm{Sn}-\beta$ zeolite was synthesized by hydrothermal methods [21,22]. Tetraethyl orthosilicate (TEOS) was hydrolyzed in an aqueous solution of tetraethylammonium hydroxide (TEAOH) under stirring. Then an aqueous solution of $\mathrm{SnCl}_{4} \cdot 5 \mathrm{H}_{2} \mathrm{O}$ was added, and the mixture was stirred until the ethanol formed by hydrolysis of TEOS was evaporated. HF was added to the clear solution obtained, and a thick paste was formed. Finally, an aqueous suspension of dealuminated nanocrystalline $(20 \mathrm{~nm}) \beta$ zeolite "seed" was added. The final gel composition was $1.0 \mathrm{SiO}_{2}: 0.008 \mathrm{SnO}_{2}: 0.54$ TEAOH:7.5 $\mathrm{H}_{2}$ O:0.54 HF. The crystallization was carried out in a Teflon-lined stainless-steel autoclave, which was heated to $413 \mathrm{~K}$ and rotated for a period of $20 \mathrm{~d}$.

\subsection{Characterization methods}

The structures of the $\beta$ zeolite samples were determined by X-ray diffraction (XRD; Rigaku D/Max 2400), using $\mathrm{Cu}$ K $\alpha$ radiation at a scanning rate of $8^{\circ} / \mathrm{min}$ between $5^{\circ}$ and $50^{\circ}$. The amount of Sn was determined using inductively coupled plasma atomic emission spectroscopy (ICP-AES; Perkin OPTIMA2000DV). Ultraviolet-visible (UV-Vis) spectra were obtained using a Shimadzu UV-550 spectrophotometer, with $\mathrm{BaSO}_{4}$ as a reference. Fourier-transform infrared (FT-IR) spectra were recorded with a Bruker EQUINOX55 spectrometer, from 4000 to $400 \mathrm{~cm}^{-1}$, using $\mathrm{KBr}$ pellets.

\subsection{Catalytic tests}

Glucose isomerization was carried out in $1 \mathrm{~mL}$ thick-walled glass reactors heated in a Reacti-Therm I Heating/Stirring Module (Thermo Scientific). In a typical run, $0.4 \mathrm{~mL}$ of an aqueous solution consisting of $10 \mathrm{wt} \%$ glucose and $30 \mathrm{mg}$ of catalyst were placed in the reactor. The reactor was sealed and put in the module at a defined temperature, under stirring, for a defined reaction time, ranging from $15 \mathrm{~min}$ to $2 \mathrm{~h}$. The reaction 
was quenched by rapid cooling in an ice bath. The reaction solution was diluted and filtered, and then a small amount of clear filtrate was removed for analysis. The samples were analyzed by high-performance liquid chromatography, using an Agilent 1200 system. Glucose and fructose were monitored using a refractive index detector with a Biorad Aminex HPX-87H column. The mobile phase was freshly prepared $0.005 \mathrm{~mol} / \mathrm{L}$ $\mathrm{H}_{2} \mathrm{SO}_{4}$; the analysis conditions were flow rate $0.5 \mathrm{~mL} / \mathrm{min}$, column temperature $338 \mathrm{~K}$, detector temperature $323 \mathrm{~K}$. A small amount of mannose was produced during the isomerization. However, the response factors of fructose and mannose are nearly identical; therefore, the column did not separate them well, so they were treated as a single compound and quantified based on the response factor of fructose. ${ }^{23}$ The amounts were calculated by an internal standard method with 1,2-propanediol as the standard.

\section{Results and discussion}

\subsection{Catalyst characterization}

As can be seen in Fig. 1, all samples (Al/B $\beta$, dealuminated/deboronated $\beta$, and isomorphously substituted Sn-Al/B $\beta$ zeolites) had obvious diffraction peaks at $2 \theta=7.80^{\circ}, 13.45^{\circ}$, $21.38^{\circ}, 22.43^{\circ}, 25.34^{\circ}, 27.09^{\circ}$, and $29.60^{\circ}$. These results demonstrated that the samples had well-defined BEA topologies [24]. The Sn-B- $\beta$ and Sn-Al- $\beta$ zeolites also had a diffraction line at $2 \theta=26.7^{\circ}$, which is characteristic of bulk $\mathrm{SnO}_{2}$. The patterns had similar diffraction intensities, indicating that no significant collapse of the crystalline structure occurred after dealumination or deboronation and $\mathrm{SnCl}_{4}$ vapor treatment.

The Sn contents of Sn- $\beta$ zeolites synthesized via different methods were determined using ICP-AES (Table 1). As can be seen, the $\mathrm{Sn}-\beta$ samples prepared using post-synthesis had much higher Sn contents than that prepared hydrothermally. In addition, B was easily removed from the framework by acid treatment, leading to an increase in the $\mathrm{Si} / \mathrm{B}$ atomic ratio from 11 to 793. The $\mathrm{Sn}$ content of the $\mathrm{Sn}-\mathrm{B}-\beta$ sample was $5.95 \%$. However, Al was relatively difficult to remove from the framework. The Si/Al atomic ratio increased from 15 to 222. The Sn content in the Sn-Al- $\beta$ sample was about $3.30 \%$. In general, the

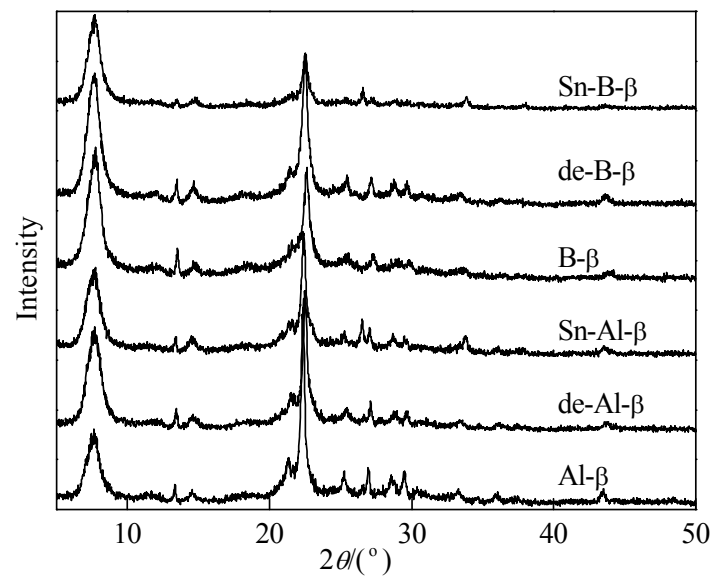

Fig. 1. XRD patterns of $\beta$ zeolite samples.
Table 1

Sn contents of $S n-\beta$ zeolites synthesized by different methods.

\begin{tabular}{lcc}
\hline Sample & $\mathrm{Si} / \mathrm{Al}$ or $\mathrm{Si} / \mathrm{B}$ & $\mathrm{SnO}_{2}$ content $(\mathrm{wt} \%)$ \\
\hline Sn- $\beta$ & - & 1.95 \\
Sn-Al- $\beta$ & 222 & 3.30 \\
Sn-B- $\beta$ & 793 & 5.95 \\
\hline
\end{tabular}

post-synthesis method improved the Sn loading on the $\beta$ zeolites, and circumvented the use of hazardous HF.

UV-Vis spectroscopy was used to verify the coordination states of $\mathrm{Sn}$ in the samples (Fig. 2). As illustrated, the three Sn- $\beta$ samples all had clear absorption bands at $\sim 220 \mathrm{~nm}$, assigned to tetrahedrally coordinated Sn in the zeolite framework [25]. Shoulder bands at $\sim 255-300 \mathrm{~nm}$ were also observed, implying the presence of extra-framework Sn species [13]. The 255-300 $\mathrm{nm}$ peak intensities of the post-synthesized samples were stronger than that of the hydrothermal sample, suggesting that more extra-framework Sn species formed during the post-synthesis procedure. The absorption band at $\sim 260 \mathrm{~nm}$ was assigned to small extra-framework $\mathrm{SnO}_{2}$ species [26]. The post-synthesized samples had an absorption band centered at $\sim 290 \mathrm{~nm}$, which indicated the formation of bulk $\mathrm{SnO}_{2}$ (assigned to hexacoordinated polymeric Sn species [27]), consistent with the XRD results. The UV-Vis band of Sn- $\beta$ centered at $\sim 260 \mathrm{~nm}$ reflects a smaller $\mathrm{SnO}_{2}$ domain [28]. All three samples contained both framework Sn and extra-framework Sn species. Unlike the hydrothermal sample, the post-synthesized samples contained bulk $\mathrm{SnO}_{2}$ species as well as framework $\mathrm{Sn}$ and small extra-framework $\mathrm{SnO}_{2}$ species.

The FT-IR spectra of the $\beta$ zeolites before and after deboronation or dealumination, and those after post-synthesis with $\mathrm{SnCl}_{4}$ vapor, are shown in Fig. 3. The Al- $\beta$ and B- $\beta$ zeolites showed obvious $\mathrm{Si}-\mathrm{O}-\mathrm{Al}$ and $\mathrm{Si}-\mathrm{O}-\mathrm{B}$ absorption bands at 960 and $956 \mathrm{~cm}^{-1}$. After treatment with acid, strong absorption bands appeared at around $960 \mathrm{~cm}^{-1}$, which indicates the formation of $\mathrm{Si}-\mathrm{OH}$ defect groups [29]. However, for the Sn- $\beta$ zeolites prepared by post-synthesis with $\mathrm{SnCl}_{4}$ vapor, the bands at around $960 \mathrm{~cm}^{-1}$ are believed to be attributable to the stretching vibrations of Si-O tetrahedra bonded to $\mathrm{Sn}$ atoms, forming $\mathrm{Si}-\mathrm{O}-\mathrm{Sn}$ bonds [30]. Furthermore, the strongest absorption

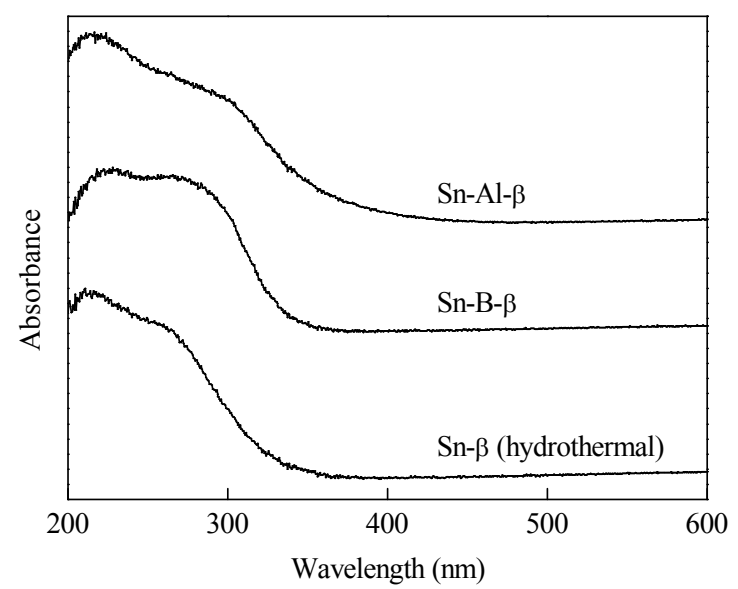

Fig. 2. UV-Vis spectra of Sn- $\beta$ samples. 

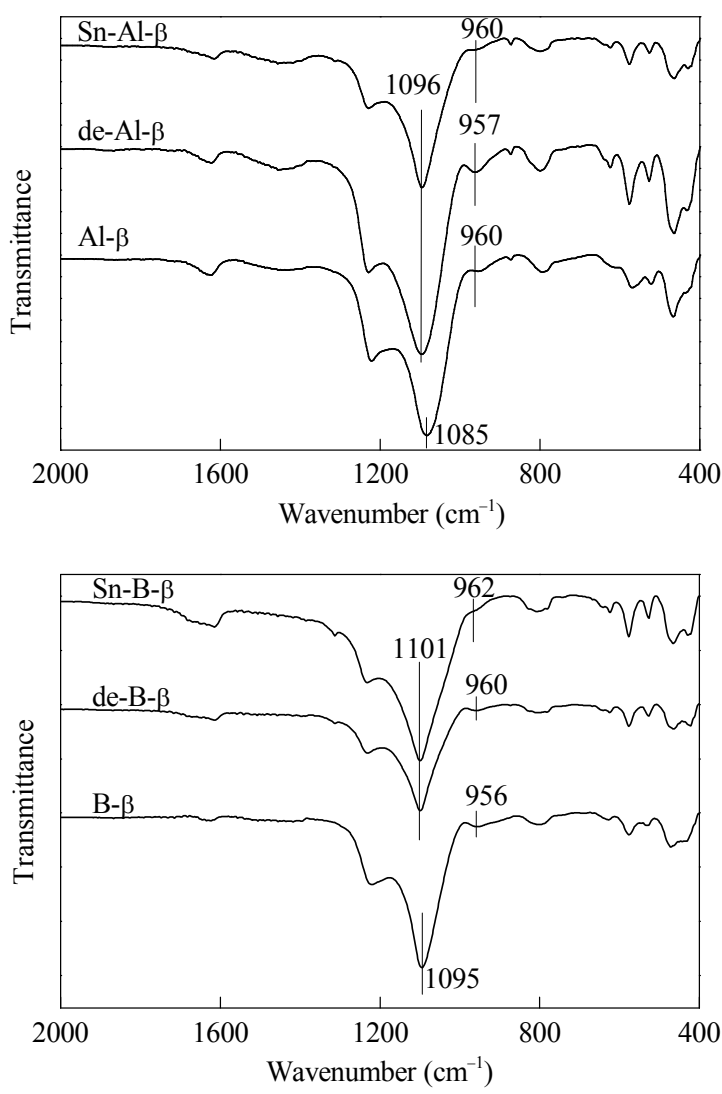

Fig. 3. FT-IR spectra of $\beta$ zeolites.

bands, at about 1085 and $1095 \mathrm{~cm}^{-1}$, for the Al- $\beta$ and B- $\beta$ zeolites, respectively, shifted to higher wave numbers after acid treatment, which also indicates that $\mathrm{Al}$ or $\mathrm{B}$ had been removed from the zeolite framework [31].

\subsection{Isomerization of glucose to fructose}

\subsubsection{Effects of reaction temperature and reaction time}

Sn- $\beta$ zeolites have been shown to be effective heterogeneous catalysts for the isomerization of glucose to fructose in aqueous solutions, and could therefore be used in biorefining of carbohydrates [16]. We therefore investigated the isomeriza- tion of glucose in the presence of the as-synthesized Sn- $\beta$ zeolites. Figure 4 shows the effects of reaction temperature and time on the isomerization reaction over the synthesized Sn-Al- $\beta$ sample. When the glucose isomerization was carried out at 353 $\mathrm{K}$ for $2 \mathrm{~h}$, the fructose yield was only $10 \%$; at $393 \mathrm{~K}$, the fructose yield increased to $\sim 40 \%$ after only $1 \mathrm{~h}$. The isomerization of glucose to fructose is slightly endothermic [16], so increasing the reaction temperature should improve the glucose conversion and fructose yield. When the temperature was further increased to $403 \mathrm{~K}$, the glucose conversion increased, but the fructose yield reached a maximum value after $0.5 \mathrm{~h}$. When the reaction time was extended, the fructose yield decreased a little; unknown products such as dehydration by-products and humins from fructose, produced at higher temperatures after longer times, may account for the decreased amount of fructose [32]. The optimum reaction conditions for glucose conversion and fructose yield were at $393 \mathrm{~K}$ for $2 \mathrm{~h}$.

\subsubsection{Effects of catalyst dosage}

The effects of catalyst dosage on the isomerization of glucose over the $\mathrm{Sn}-\mathrm{Al}-\beta$ zeolite were investigated; the results are shown in Fig. 5. A blank test (393 K, 2 h) showed that the isomerization of glucose to fructose could not proceed without a catalyst in an aqueous medium. When $10 \mathrm{mg}$ of catalyst was added to the glucose solution, the glucose conversion and fructose yield were $\sim 40 \%$ and $\sim 30 \%$, respectively. When the catalyst dosage was increased to $20 \mathrm{mg}$, the glucose conversion and fructose yield increased to more than $50 \%$ and $40 \%$, respectively. Further increases in the catalyst dosage had a negligible effect on the fructose yield, but the glucose conversion was significantly improved, possibly because the amount of Sn-Al- $\beta$ catalyst $(20 \mathrm{mg}$ ) was already sufficient for glucose isomerization under the specified conditions, and the Lewis acidity of the excess catalyst caused more side reactions.

The XRD and UV-Vis results suggest that more extraframework small $\mathrm{SnO}_{2}$ species and bulk $\mathrm{SnO}_{2}$ are present in the post-synthesized samples than in the hydrothermal sample. When the reaction conditions were water as the solvent, glucose concentration $10 \mathrm{wt} \%$, reaction temperature $393 \mathrm{~K}$, and time $2 \mathrm{~h}$, the glucose conversions over the hydrothermal Sn- $\beta$, Sn-Al- $\beta$, and Sn-B- $\beta$ zeolites were $\sim 66 \%, \sim 66 \%$, and $\sim 65 \%$,

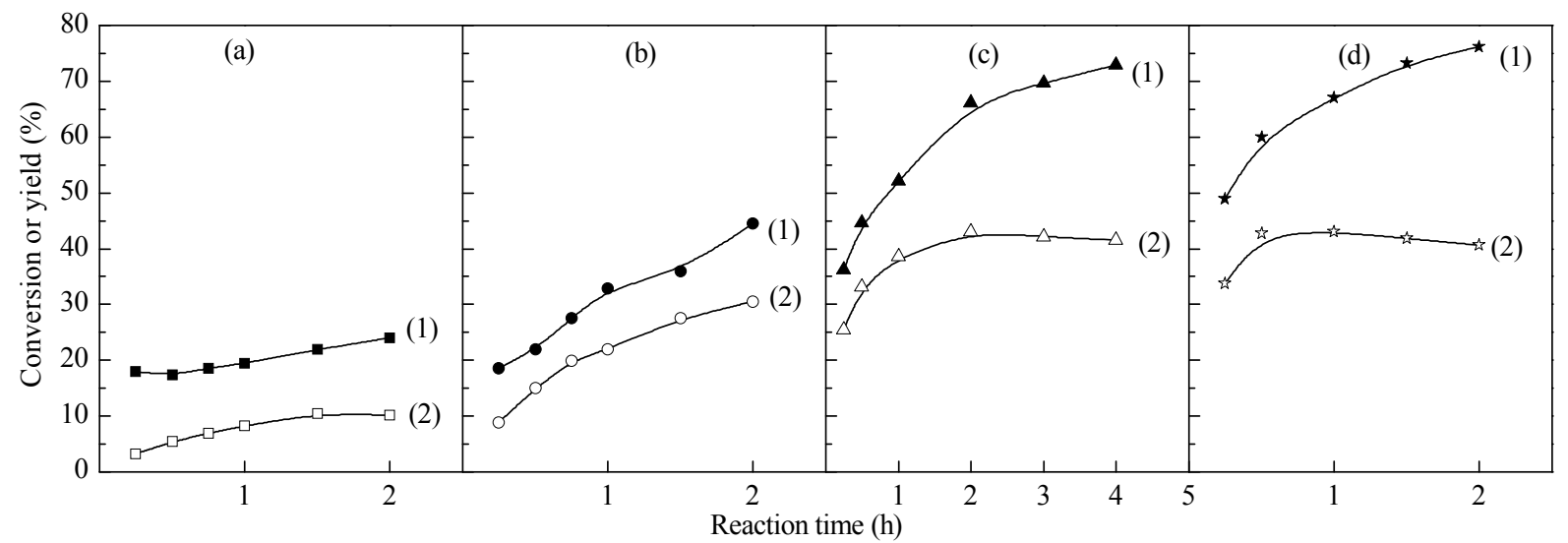

Fig. 4. Effects of reaction temperature and reaction time on isomerization of glucose to fructose over Sn-Al- $\beta$ catalyst. (a) $353 \mathrm{~K}$; (b) $373 \mathrm{~K}$; (c) $393 \mathrm{~K}$; (d) 403 K. (1) Glucose conversion; (2) Fructose yield. Reaction conditions: $10 \mathrm{wt} \%$ glucose aqueous solution $0.4 \mathrm{~mL}$, Sn-Al- $\beta 30 \mathrm{mg}$. 


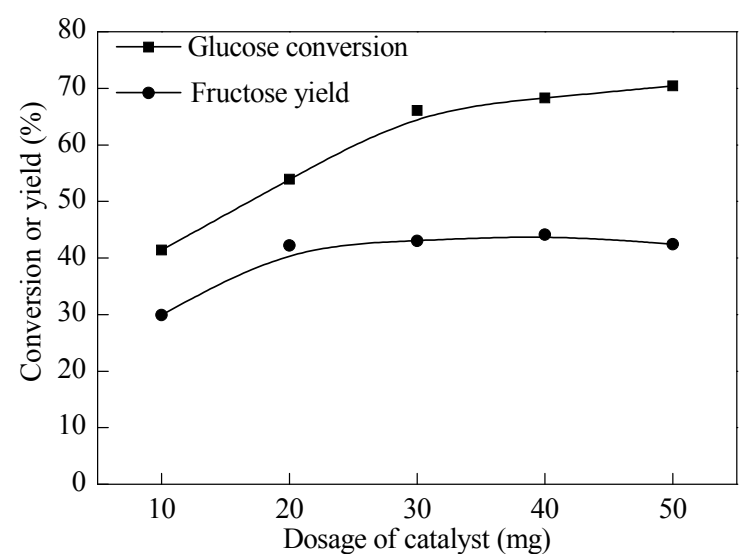

Fig. 5. Effect of Sn-Al- $\beta$ catalyst dosage on isomerization of glucose to fructose. Reaction conditions: $10 \mathrm{wt} \%$ glucose aqueous solution $40 \mathrm{~mL}$ $393 \mathrm{~K}, 2 \mathrm{~h}$.

respectively, and the fructose yields were $\sim 46 \%, \sim 43 \%$, and $\sim 43 \%$, respectively. This indicated that the extra-framework $\mathrm{SnO}_{2}$ and bulk $\mathrm{SnO}_{2}$ did not negatively affect glucose isomerization. It is generally accepted that only framework Sn species provide active sites for reactions with $\mathrm{Sn}-\beta$ zeolite catalysts $[21,23]$, so it is concluded that all three Sn-containing samples had similar amounts of framework Sn species.

\subsubsection{Effects of solvent}

The effects of the solvent on the isomerization of glucose to fructose were investigated, and the results are shown in Fig. 6. Three ionic liquids with different anions, namely 1-butyl-3methylimidazolium chloride $([\mathrm{bmim}] \mathrm{Cl})$, 1-ethyl-3-methylimidazolium bromide ([emim]Br), and 1-butyl-3-methylimidazolium hexafluorophosphate ([bmim] $\left.\mathrm{PF}_{6}\right)$, and three strongly polar organic solvents, namely $\mathrm{N}, \mathrm{N}$-dimethylformamide (DMF), $\mathrm{N}, \mathrm{N}$-dimethylacetamide (DMA), and dimethyl sulfoxide (DMSO), were used. Glucose was completely soluble in all these solvents. When the ionic liquids were used as the solvents, no fructose was produced, although significant glucose conversions were observed. In terms of possible glucose isomerization mechanisms [33], ionic liquids could inhibit contact and reaction between the $\mathrm{Sn}-\beta$ zeolite and glucose molecules. As

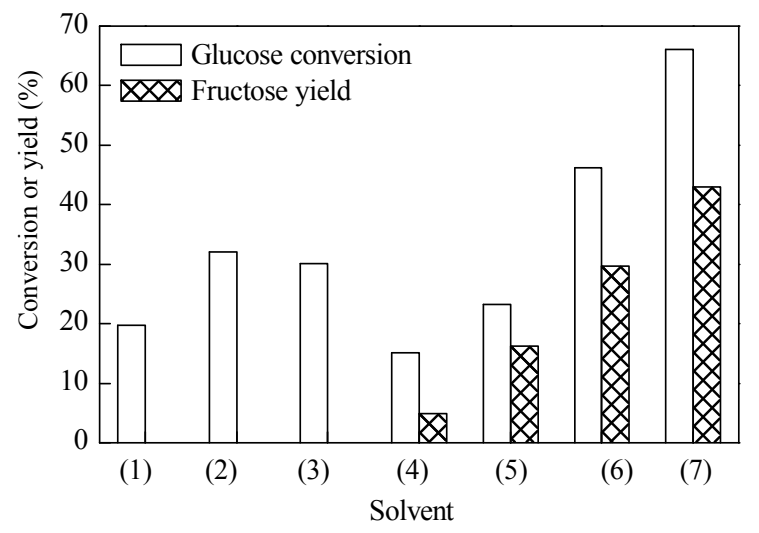

Fig. 6. Isomerization of glucose to fructose in different solvents. (1) [bmim]Cl; (2) [emim]Br; (3) [bmim]PF6; (4) DMSO; (5) DMF; (6) DMA; (7) Water. Reaction conditions: glucose monohydrate $50 \mathrm{mg}$, solvent $0.4 \mathrm{~mL}$, Sn-Al- $\beta$ catalyst $30 \mathrm{mg}, 393 \mathrm{~K}, 2 \mathrm{~h}$.

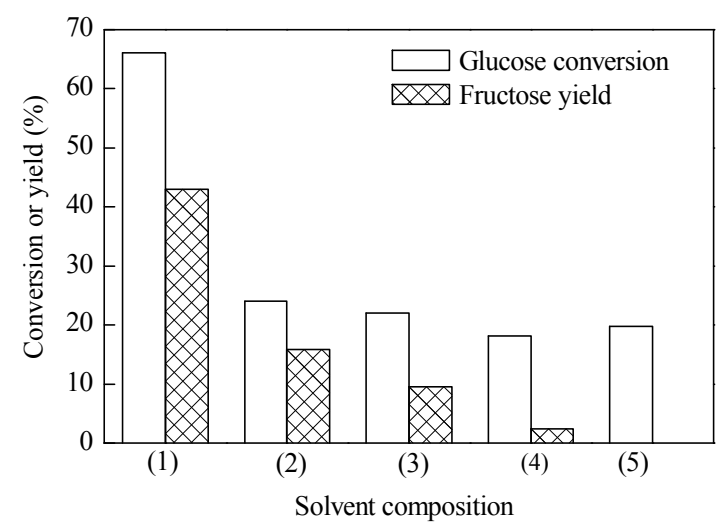

Fig. 7. Effects of solvent composition on isomerization of glucose to fructose. (1) $0.4 \mathrm{~mL} \mathrm{~A}$; (2) $0.3 \mathrm{~mL} \mathrm{~A}+0.1 \mathrm{~mL} \mathrm{~B}$; (3) $0.2 \mathrm{~mL} \mathrm{~A}+0.2 \mathrm{~mL} \mathrm{~B}$; (4) $0.1 \mathrm{~mL} \mathrm{~A} \mathrm{+} 0.3 \mathrm{~mL} \mathrm{~B}$; (5) $0.4 \mathrm{~mL} \mathrm{~B}$. A water; B [bmim]Cl. Reaction conditions: glucose monohydrate $50 \mathrm{mg}$, Sn-Al- $\beta$ catalyst $30 \mathrm{mg}$, $393 \mathrm{~K}$, $2 \mathrm{~h}$.

shown in Fig. 7, the fructose yield decreased continuously with increasing proportion of ionic liquid in the mixed solvent. However, when organic solvents were used in the reaction system, the fructose yields were $4.9 \%, 16.2 \%$, and $29.7 \%$ in DMSO, DMF, and DMA, respectively, possibly because the organic solvents, which are Lewis bases, competed with glucose for the Lewis acid sites in the Sn-Al- $\beta$ zeolite. Strong interactions between Lewis acid centers in zeolites and hydroxyl/ carbonyl moieties in reactants dissolved in organic solvents have been reported previously [34].

\subsubsection{Effects of sodium halide additives}

Ionic liquids such as [bmim] Cl essentially suppressed glucose isomerization, so it was speculated that the anion could be an influential factor. Experiments were performed to examine the effects of anions. Various sodium halides, i.e., $\mathrm{NaF}, \mathrm{NaCl}$, $\mathrm{NaBr}$, and $\mathrm{NaI}$, were used as additives under the same reaction conditions. The glucose conversions and fructose yields are listed in Table 2. The results indicated that under these reaction conditions, no cross reactions occurred. NaI had a negligible

\section{Table 2}

Effects of sodium halide additives on isomerization of glucose to fructose.

\begin{tabular}{lccc}
\hline Dosage (mg) & Salt & Glucose conversion (\%) & Fructose yield (\%) \\
\hline- & - & 66.1 & 43.0 \\
10 & $\mathrm{NaF}$ & 40.3 & 20.1 \\
10 & $\mathrm{NaCl}$ & 62.1 & 33.6 \\
10 & $\mathrm{NaBr}$ & 63.1 & 33.1 \\
10 & $\mathrm{NaI}$ & 65.1 & 38.0 \\
30 & $\mathrm{NaF}$ & 37.4 & 22.8 \\
30 & $\mathrm{NaCl}$ & 56.4 & 28.9 \\
30 & $\mathrm{NaBr}$ & 52.4 & 27.0 \\
30 & $\mathrm{NaI}$ & 64.8 & 37.1 \\
50 & $\mathrm{NaF}$ & 35.2 & 22.6 \\
50 & $\mathrm{NaCl}$ & 52.4 & 25.7 \\
50 & $\mathrm{NaBr}$ & 49.2 & 24.6 \\
50 & $\mathrm{NaI}$ & 61.6 & 35.7 \\
\hline Reaction conditions: 10 wt\% glucose aqueous solution $0.4 \mathrm{~mL}, \mathrm{Sn}-\mathrm{Al}-\beta$ \\
30 mg, 393 K, 2 h.
\end{tabular}


Table 3

Reusability of Sn-Al- $\beta$ catalyst in glucose isomerization.

\begin{tabular}{lcc}
\hline Sample & Glucose conversion (\%) & Fructose yield (\%) \\
\hline Fresh catalyst & 54.7 & 43.2 \\
Regeneration I & 57.2 & 45.6 \\
Regeneration II & 56.9 & 46.5 \\
Regeneration III & 59.9 & 45.8 \\
\hline
\end{tabular}

Reaction conditions: $10 \mathrm{wt} \%$ glucose aqueous solution $8.0 \mathrm{~mL}, \mathrm{Sn}-\mathrm{Al}-\beta$ $600 \mathrm{mg}, 393 \mathrm{~K}, 2 \mathrm{~h}$.

effect on the reaction, but $\mathrm{NaCl}$ and $\mathrm{NaBr}$ inhibited the isomerization reaction to a certain degree. When the dosages of $\mathrm{NaCl}$ and $\mathrm{NaBr}$ were increased from $10 \mathrm{mg}$ to $50 \mathrm{mg}$, the fructose yields decreased from $\sim 33 \%$ to about $\sim 25 \%$. This indicated that chloride and bromide anions probably interacted with the active sites, i.e., Sn centers, thereby suppressing glucose isomerization and leading to decreased fructose yields. NaF significantly lowered the fructose yield. When only $10 \mathrm{mg}$ of $\mathrm{NaF}$ were added to the mixture, the fructose yield dropped from $\sim 43 \%$ to $\sim 20 \%$. It was previously reported that sodium halides increased the salting-out effect on glucose in aqueous solutions $[35,36]$. The order of the salting coefficients $\left(k_{\mathrm{s}}\right)$ are as follows: $\mathrm{NaF}>\mathrm{NaCl}>\mathrm{NaBr}$. NaF had the strongest salting-out effect on glucose. These results show that the fructose yields were related to the salting-out effects of sodium halides. The isomerization of glucose to fructose over the $\mathrm{Sn}-\mathrm{Al}-\beta$ catalyst was high in water without sodium halides, which could be the reason for [bmim] $\mathrm{Cl}$ had a negative effect on the isomerization, as shown in Fig. 6.

\subsubsection{Catalyst reusability}

The Sn-Al- $\beta$ zeolite was used to study the reusabilities of the synthesized zeolites in the isomerization of glucose. It was found that carbonaceous deposits formed during the reaction, resulting in a decrease in the fructose yield from $43.2 \%$ in the first run to $39.8 \%$ in the second run (without regeneration; the catalyst was filtered and dried at $393 \mathrm{~K}$ before reuse). To eliminate the effects of carbonaceous deposits, the Sn-Al- $\beta$ catalyst was regenerated by calcination at $813 \mathrm{~K}$ for $4 \mathrm{~h}$ after each run, and reused four times. The results are listed in Table 3. (When the reaction was scaled up by a factor of 20 , the glucose conversion was a little lower than those in Fig. 1, possibly because of reduced stirring efficiency.) These results show that there are no substantial changes in the glucose conversion and fructose yield over the regenerated catalyst compared with those over the fresh catalyst, indicating that the as-synthesized Sn- $\beta$ catalysts can effectively be separated and reused.

\section{Conclusions}

In this work, a facile preparation of $\mathrm{Sn}-\beta$ zeolites by post-synthesis is presented. The post-synthesis method consisted of two procedures, i.e., heteroatom removal and isomorphous substitution by reaction with $\mathrm{SnCl}_{4}$; the preparation time was reduced from about $40 \mathrm{~d}$ (reported for zeolites prepared hydrothermally) to less than $1 \mathrm{~d}$, and the use of hazardous HF was avoided. The Sn contents of the Sn- $\beta$ zeolites syn- thesized using the post-synthesis procedure were higher than that of the zeolite prepared using a hydrothermal method, and both framework and extra-framework Sn species were present. The activities of the as-synthesized Sn- $\beta$ zeolites in the isomerization of glucose to fructose in aqueous solutions were comparable to that of the zeolite synthesized hydrothermally. The maximum fructose yield of $\sim 43 \%$ was obtained at a glucose conversion of $\sim 66 \%$ at $393 \mathrm{~K}$ for $2 \mathrm{~h}$. It was found that the reaction solvent played a key role in the isomerization of glucose; water was the best solvent. Ionic liquids suppressed the Sn$\beta$-zeolite-catalyzed isomerization of glucose. Low or moderate yields of fructose were achieved in organic solvents such as DMSO, DMF, and DMA, possibly because the organic solvents, which are Lewis bases, competed with glucose for the Lewis acid sites in the Sn-Al- $\beta$ zeolite. The as-synthesized $\mathrm{Sn}-\beta$ zeolites could be reused three times in the isomerization of glucose to fructose without loss of activity, after regeneration procedures. These facilely prepared Sn- $\beta$ zeolites have potential applications in biomass conversion.

\section{References}

[1] Nigam P S, Singh A. Prog Energy Combust Sci, 2011, 37: 52

[2] Chheda J N, Huber G W, Dumesic J A. Angew Chem Int Ed, 2007, 46: 7164

[3] Climent M J, Corma A, Iborra S. Green Chem, 2011, 13: 520

[4] Kunkes E L, Simonetti D A, West R M, Serrano-Ruiz J C, Gartner C A, Dumesic J A. Science, 2008, 322: 417

[5] Caes B R, Raines R T. ChemSusChem, 2011, 4: 353

[6] Zhao H, Holladay J E, Brown H, Zhang Z C. Science, 2007, 316: 1597

[7] Bicker M, Hirth J, Vogel H. Green Chem, 2003, 5: 280

[8] Corma A, Iborra S, Velty A. Chem Rev, 2007, 107: 2411

[9] Takagaki A, Ohara M, Nishimura S, Ebitani K. Chem Commun, 2009: 6276

[10] Nikolla E, Roman-Leshkov Y, Moliner M, Davis M E. ACS Catal, 2011, 1: 408

[11] Yang B Y, Montgomery R. Carbohydr Res, 1996, 280: 27

[12] De Wit G, Kieboom A P G, van Bekkum H. Carbohydr Res, 1979, 74: 157

[13] Li P, Liu G Q, Wu H H, Liu Y M, Jiang J G, Wu P. J Phys Chem C, 2011, 115: 3663

[14] Corma A, Renz M. Chem Commun, 2004: 550

[15] Corma A, Domine M E, Valencia S. J Catal, 2003, 215: 294

[16] Moliner M, Roman-Leshkov Y, Davis M E. PNAS, 2010, 107: 6164

[17] Chang C C, Wang Z, Dornath P, Cho H J, Fan W. RSC Adv, 2012, 2: 10475

[18] Choudhary V, Pinar A B, Sandler S I, Vlachos D G, Lobo R F. ACS Catal, 2011, 1: 1724

[19] Lew C M, Rajabbeigi N, Tsapatsis M. Ind Eng Chem Res, 2012, 51: 5364

[20] Liu M, Guo X W, Wang X S. Chin J Catal (刘民, 郭新闻, 王祥生. 催 化学报), 2004, 25: 169

[21] Corma A, Nemeth L T, Renz M, Valencia S. Nature, 2001, 412: 423

[22] Valencia S, Corma A. US Patent 5968473. 1999

[23] Osmundsen C M, Holm M S, Dahl S, Taarning E. Proc R Soc A Math Phys Eng Sci, 2012, 468: 2000

[24] Higgins J B, Lapierre R B, Schlenker J L, Rohrman A C, Wood J D, Kerr G T, Rohrbaugh W J. Zeolites, 1988, 8: 446

[25] van Grieken R, Martos C, Sanchez-Sanchez M, Serrano D P, Melero J A, Iglesias J, Cubero A G. Microporous Mesoporous Mater, 2009, 


\title{
Graphical Abstract
}

Chin. J. Catal., 2014, 35: 723-732 doi: 10.1016/S1872-2067(14)60071-1

\section{Facile preparation of $\mathrm{Sn}-\boldsymbol{\beta}$ zeolites by post-synthesis (isomorphous substitution) method for isomerization of glucose to fructose}

Min Liu*, Songyan Jia, Changzeng Li, Anfeng Zhang, Chunshan Song, Xinwen Guo* Dalian University of Technology, China; Dalian Institute of Chemical Physics, Chinese Academy of Sciences, China; Pennsylvania State University, United States

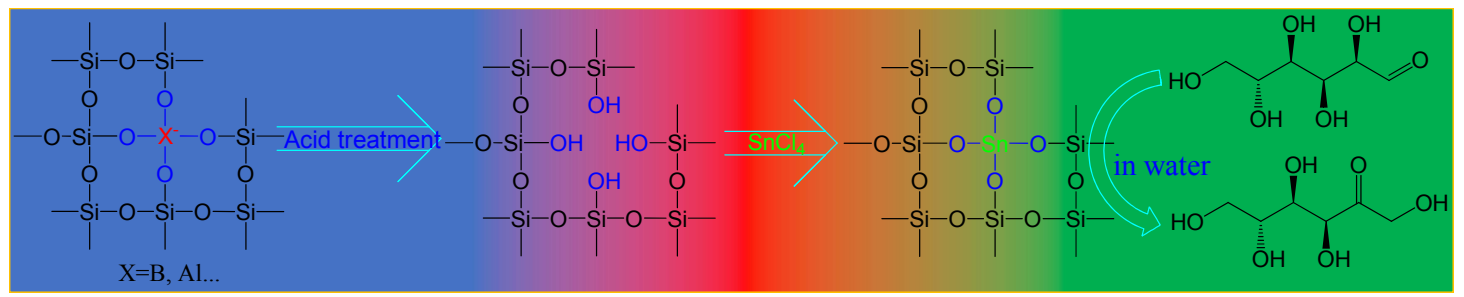

Sn- $\beta$ zeolites were facilely synthesized using a post-synthesis method, which significantly shortened the preparation time. The effects of the reaction conditions on glucose isomerization over the Sn- $\beta$ zeolites were studied in detail.

119: 176

[26] Gu F, Wang S F, Song C F, Lü M K, Qi Y X, Zhou G J, Xu D, Yuan D R. Chem Phys Lett, 2003, 372: 451

[27] Mal N K, Ramaswamy A V.J Mol Catal A, 1996, 105: 149

[28] Bermejo-Deval R, Gounder R, Davis M E. ACS Catal, 2012, 2: 2705

[29] Blasco T, Camblor M A, Corma A, Esteve P, Guil J M, Martinez A, Perdigon-Melon J A, Valencia S. J Phys Chem B, 1998, 102: 75

[30] Boronat M, Concepción P, Corma A, Renz M, Valencia S. J Catal, 2005, 234: 111

[31] Sohn J R, Decanio S J, Lunsford J H, Odonnell D J. Zeolites, 1986, 6:

\section{5}

[32] Qi X H, Watanabe M, Aida T M, Smith R L. Catal Commun, 2009, 10: 1771

[33] Roman-Leshkov Y, Moliner M, Labinger J A, Davis M E. Angew Chem Int Ed, 2010, 49: 8954

[34] Corma A, Garcia H. Chem Rev, 2002, 102: 3837

[35] Dong W, Zhao Y, Zhuo K, Chen Y. Ind Eng Chem Res, 2010, 49: 9430

[36] Dong W Y, Zhang X K, Zhuo K L, Wang J J. J Henan Nomal Univ (Natural Sci) (董伟燕, 张心宽, 卓克垒, 王键吉. 河南师范大学学 报(自然科学版)), 2009, 37: 188

\section{二次法(同晶取代)快速合成Sn- $\boldsymbol{\beta}$ 沸石用于葡萄糖异构制果糖}

\author{
刘民党, 贾松岩 ${ }^{\mathrm{b}}$, 李常增 ${ }^{\mathrm{a}}$, 张安峰 ${ }^{\mathrm{a}}$, 宋春山 ${ }^{\mathrm{a}, \mathrm{c}, \mathrm{d}}$, 郭新闻 ${ }^{\mathrm{a}, \#}$ \\ a 大连理工大学精细化工国家重点实验室, 化工学院催化化学与工程系, 辽宁大连 116012 \\ ${ }^{\mathrm{b}}$ 中国科学院大连化学物理研究所洁净能源国家实验室(筹), 辽宁大连 116023

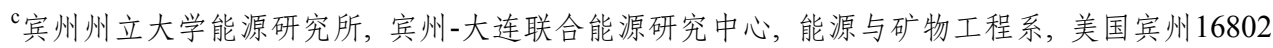

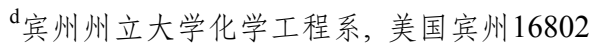

摘要: 采用二次法快速合成了 $\mathrm{Sn}-\beta$ 沸石. 该方法包含杂原子脱除和与 $\mathrm{SnCl}_{4}$ 的同晶取代两个步骤, 合成时间从水热法的约 $40 \mathrm{~d}$ 缩 短为少于 $1 \mathrm{~d}$, 且 $\mathrm{Sn}$ 含量更高. 将该沸石用于水相催化葡萄糖异构化制果糖反应，详细考察了反应温度、时间、催化剂用量、溶剂 以及卤盐添加物对反应性能的影响. 在优化的反应条件下，果糖收率最高可达约 $43 \%$. 催化剂可以通过焙烧再生.

关键词: Sn- $\beta$; 同晶取代; 葡萄糖; 异构化; 果糖

收稿日期: 2014-02-27. 接受日期: 2014-03-10. 出版日期: 2014-05-20.

*通讯联系人. 电话/传真: (0411)84986134; 电子信箱: lium@dlut.edu.cn

\#通讯联系人. 电话: (0411)84986133; 传真: (0411)84986134; 电子信箱: guoxw@dlut.edu.cn

基金来源：国家自然科学基金 (20803005, 21306186).

本文的英文电子版由Elsevier出版社在ScienceDirect上出版(http://www.sciencedirect.com/science/journal/18722067).

\section{1. 前言}

随着大量化石能源的使用和随之而来的严重环境 问题，人们越来越重视可再生能源的开发利用 ${ }^{[1]}$. 由于 具有可再生和碳平衡的特点, 生物质被认为是生产生物
基化学品的重要原料 ${ }^{[1]}$. 糖催化转化制备高附加值化学 品, 如5-差欮甲基糠醛(HMF), 已经取得了进展 ${ }^{[2-4]}$. HMF 是一种多用途化学中间体, 可以经由酸催化果糖水解得 到 $^{[5-7]}$. 然而, 果糖在自然界中的储量低, 增加了 $\mathrm{HMF}$ 的制备成本. 而葡萄糖是自然界储量最大、分布最广泛 
的单糖，有望成为制备 $\mathrm{HMF}$ 的绝佳原料 ${ }^{[8]}$. Zhao 等 ${ }^{[6]}$ 首 次报道了离子液体中 $\mathrm{CrCl}_{3}$ 催化葡萄糖制得 $\mathrm{HMF}$. 葡萄 糖直接转化为 HMF 实际包含两个步骤: 葡萄糖异构为 果糖和果糖脱水得到 $\mathrm{HMF}^{[9,10]}$, 其中第一步是该反应的 关键.

典型的葡萄糖异构工艺有碱催化和酶催化技术. 碱 催化需要过量的有机碱水溶液, 而果糖在强碱体系中极 不稳定 ${ }^{[11,12]}$; 虽然酶催化可高效制备果糖，但操作条件 过于敏感，如 $\mathrm{pH}$ 值，温度，原料纯度等，而且反应时间 一般很长.

Sn- $\beta$ 是一种含有 $L$ 酸的多相催化剂，已用于很多反 应中: 如环酮的Baeyer-Villiger (BV) 氧化反应 ${ }^{[13]}$, 香茅 醛环化为异薄勒醇 ${ }^{[14]}$, 以及 Meerwein-Ponndorf-VerleyOppenauer氧化还原反应 ${ }^{[15]}$. 最近, Moliner等 ${ }^{[16]}$ 以 Sn- $\beta$ 为催化剂成功在水溶液中将葡萄糖异构为果糖. 另外, Sn- $\beta$ 沸石还可用于木糖异构化，葡萄糖一锅法制备 HMF或5-乙氧基甲基糠醛 ${ }^{[10,17,18]}$. 采用水热法制备 Sn- $\beta$ 沸石的晶化时间太长, 约 $40 \mathrm{~d}$; 即使采用快速合成法也 需要大约 $2 \mathrm{~d}^{[17]}$. 同时, 上述合成过程都使用氟化 物 ${ }^{[13,17-19]}$. 因此, 迫切需要一种环保而快速的制备 Sn- $\beta$ 的路线. 二次合成法(同晶取代)经由高硅沸石和金属氯 化物的气固相反应可以将大量金属原子插入到沸石骨 架中, 且不需要水热晶化, 大大缩短了时间 ${ }^{[10,13,16-18]}$. 因此，从经济和环保角度考虑，二次合成法在 $S n-\beta$ 合成 中具有很大优势.

本文采用脱铝/脱硼沸石与 $\mathrm{SnCl}_{4}$ 气固相反应快速制 备 $\mathrm{Sn}-\beta$ 沸石, 并研究了该沸石在水溶液中催化葡萄糖异 构制果糖的性能.

\section{2. 实验部分}

\section{1. 试剂}

无水 $\mathrm{SnCl}_{4}(\mathrm{AR})$ 购自国药集团. 一水葡萄糖(AR) 购自天津科密欧化学试剂有限公司. 硝酸 $(65 \%, \mathrm{AR})$ 购 自北京化学试剂厂. Al- $\beta$ 沸石来自沈阳化工大学. B- $\beta$ 由 大连理工大学合成. 去离子水由大连理工大学提供. 所 有试剂在使用前均未进行进一步提纯.

\section{2. 催化剂制备}

采用二次合成法制备 $\mathrm{Sn}-\mathrm{Al}-\beta$ (以Al- $\beta$ 为前驱体) ${ }^{[13]}$. 制备过程包括脱铝和 $\mathrm{SnCl}_{4}$ 同晶取代两步. $\mathrm{Al}-\beta$ ( $\mathrm{H}$ 型, $\mathrm{Si} / \mathrm{Al}$ 摩尔比 15$)$ 以 $4 \mathrm{~mol} / \mathrm{L}$ 硝酸在 $348 \mathrm{~K}$ 下脱铝 $2 \mathrm{~h}$, 固液 比 $1 \mathrm{~g} / 10 \mathrm{ml}$, 然后空气中 $393 \mathrm{~K}$ 干燥 $2 \mathrm{~h}, 813 \mathrm{~K}$ 焙烧 $5 \mathrm{~h}$, 得到高硅沸石 $(\mathrm{Si} / \mathrm{Al}$ 摩尔比 221$)$; 再置于石英管反应器
中于 $813 \mathrm{~K}$ 用 $\mathrm{N}_{2}$ 吹扫 $2 \mathrm{~h}$. 然后切换为夹带 $\mathrm{SnCl}_{4}$ 蒸汽的 $\mathrm{N}_{2}$. 反应一定时间后，重新切换为纯 $\mathrm{N}_{2}$ 吹扫 $2 \mathrm{~h}$ 以除去 残余未反应的 $\mathrm{SnCl}_{4}$. 降温至室温. 样品用乙醇洗涤3次, 并在空气中于 $373 \mathrm{~K}$ 干燥过夜, 最后在空气中 $813 \mathrm{~K}$ 焙烧 $4 \mathrm{~h}$.

采用二次法制备 Sn-B- $\beta$ (以B- $\beta$ 为前驱体) ${ }^{[20]}$. 将 B- $\beta$ 沸石 $(\mathrm{Si} / \mathrm{B}$ 摩尔比 11$)$ 用 $1 \mathrm{~mol} / \mathrm{L}$ 盐酸在 $333 \mathrm{~K}$ 下处理 2 $\mathrm{h}$, 固液比 $1 \mathrm{~g} / 10 \mathrm{ml}$, 得到高硅沸石 $(\mathrm{Si} / \mathrm{B}$ 摩尔比793). 随 后的同晶取代过程与Al- $\beta$ 相同.

为了比较, 采用水热法制备 $S n-\beta$ 沸石 ${ }^{[21,22]}$. 首先将 正硅酸乙酯(TEOS)在四乙基氢氧化铵(TEAOH)水溶液 中搅拌水解. 然后加入 $\mathrm{SnCl}_{4} \cdot 5 \mathrm{H}_{2} \mathrm{O}$ 水溶液, 摚拌, 直到 TEOS水解产生的乙醇挥发完全. 加入 $\mathrm{HF}$, 得到粘稠糊 状物. 最后, 加入晶种, 即 $20 \mathrm{~nm}$ 粒度脱铝 $\beta$ 沸石纳米晶 悬浊液. 最终胶液组成为 $1.0 \mathrm{SiO}_{2}: 0.008 \mathrm{SnO}_{2}: 0.54$ TEAOH: $7.5 \mathrm{H}_{2} \mathrm{O}: 0.54 \mathrm{HF}$. 在聚四氟乙烯内祄高压釜中于 $413 \mathrm{~K}$ 晶化 $20 \mathrm{~d}$.

\section{3. 催化剂表征}

$\beta$ 沸石的X射线衍射 (XRD) 表征在 Rigaku D/Max 2400 型X射线衍射仪上进行. $\mathrm{Cu} K_{\alpha}$ 辐射源, 扫描速度 $8^{\circ} / \mathrm{min}$, 扫面范围 $5^{\circ}-50^{\circ}$. Sn含量用电感耦合等离子体原 子发射光谱 (ICP-AES) 测定, 仪器为 Perkin OPTIMA2000DV型原子发射光谱仪. 紫外-可见光谱(UV-Vis)在 Shimadzu UV-550型光谱仪上测得, $\mathrm{BaSO}_{4}$ 做参比. 傅立 叶红外光谱(FT-IR)在Bruker EQUINOX55光谱仪上测 得, 波数 $4000-400 \mathrm{~cm}^{-1}$, 采用 $\mathrm{KBr}$ 压片技术.

\section{4. 催化剂评价}

葡萄糖异构化反应在配备有Reacti-Therm I 型加热/ 搅拌模块的 $1 \mathrm{ml}$ 厚壁玻璃反应器(赛默飞世尔)中进行. 典型过程是, $0.4 \mathrm{ml}$ 葡萄糖水溶液 $(10 \mathrm{wt} \%$ )和 $30 \mathrm{mg}$ 催化 剂加入反应器并密封, 加热并搅拌 $15 \mathrm{~min} 2 \mathrm{~h}$ 后, 将反 应器放入冰浴中使反应终止. 反应液稀释分离后, 取部 分滤液进行产物分析. 产物分析在安捷伦 1200 型高效液 相色谱上进行, 示差检测器, Biorad Aminex HPX-87H色 谱柱, 流动相 $0.005 \mathrm{~mol} / \mathrm{L} \mathrm{H}_{2} \mathrm{SO}_{4}$. 检测条件: 流速 0.5 $\mathrm{ml} / \mathrm{min}$, 柱温 $338 \mathrm{~K}$, 检测器温度 $323 \mathrm{~K}$. 异构化过程中 生成微量甘露糖, 由于色谱柱不能完全区分甘露糖和果 糖, 所以, 将甘露糖作为果糖处理 ${ }^{[23]}$. 以 1,2 -丙二醇为 内标物计算组分含量.

\section{3. 结果与讨论}

\section{1. 催化剂的表征}


图1为Al- $\beta, \mathrm{B}-\beta$, 脱铝后的 $\beta$, 脱嗍后的 $\beta$, Sn-B- $\beta$ 和 Sn-Al- $\beta$ 样品的XRD谱. 由图可见, 各样品均在 $2 \theta=$ $7.80^{\circ}, 13.45^{\circ}, 21.38^{\circ}, 22.43^{\circ}, 25.34^{\circ}, 27.09^{\circ}, 29.60^{\circ}$ 处有明 显衍射峰, 说明均具有 BEA拓扑结构 ${ }^{[24]}$. Sn-B- $\beta$ 和 Sn-Al- $\beta$ 在 $2 \theta=26.7^{\circ}$ 处出现表征大颗粒 $\mathrm{SnO}_{2}$ 的衍射峰. 另外, 各样品特征衍射峰强度相近, 说明脱硼/脱铝以及 $\mathrm{SnCl}_{4}$ 气固相反应过程没有对沸石骨架结构造成明显破 坏.

不同方法合成的 $S n-\beta$ 沸石的 $S n$ 含量见表 1 . 由于 $B$ 很容易从骨架中酸处理脱除, 所以 $\mathrm{Sn}-\mathrm{B}-\beta$ 中的 $\mathrm{Si} / \mathrm{B}$ 摩尔 比由 11 上升到 $793 ; \mathrm{Sn}$ 含量高达 $5.95 \%$. 而 $\mathrm{Al}$ 从骨架中的 脱除相对困难, Sn-Al- $\beta$ 中的Si/A1摩尔比仅由 15 升到 222 , $\mathrm{Sn}$ 含量约为 $3.30 \%$. 由此可见, 与水热法相比, 二次法 提高了 $\mathrm{Sn}-\beta$ 沸石的 $\mathrm{Sn}$ 含量, 且避免使用有毒的HF.

图 2 为三个 Sn- $\beta$ 样品的UV-Vis谱. 可以看出, 各样 品均在 $220 \mathrm{~nm}$ 附近出现表征骨架 $\mathrm{Sn}$ 的明显吸收 ${ }^{[25]}$. 位 于255-300 $\mathrm{nm}$ 的肩峰说明样品中同时含有非骨架 $\mathrm{Sn}^{[13]}$, 其中二次合成法样品的峰强度强于水热法样品, 说明二 次合成过程中生成了更多的非骨架 $\mathrm{Sn}$. $260 \mathrm{~nm}$ 附近的吸 收归属于小颗粒的非骨架 $\mathrm{SnO}_{2}$ 物种 ${ }^{26]}$. 二次合成样品 中 $290 \mathrm{~nm}$ 处的吸收归属于大颗粒 $\mathrm{SnO}_{2}$ (六配位聚合 $\mathrm{Sn}$ 物 种 $\left.^{[27]}\right)$, 与XRD结果一致. 较低的吸收中心位置( 260 $\mathrm{nm})$ 说明水热法 $\mathrm{Sn}-\beta$ 中主要是小颗粒的 $\mathrm{SnO}_{2}{ }^{[28]}$. 可见, 与水热法样品不同的是, 二次法样品除了含有骨架 $\mathrm{Sn}$ 和 小颗粒的非骨架 $\mathrm{SnO}_{2}$, 还含有大颗粒的非骨架 $\mathrm{SnO}_{2}$.

脱铝/脱嗍前后以及同晶取代以后的B沸石的FT-IR 谱见图3. 可以看出, Al- $\beta$ 和B- $\beta$ 均有明显的表征 $\mathrm{Si}-\mathrm{O}-\mathrm{Al}$ 键和 $\mathrm{Si}-\mathrm{O}-\mathrm{B}$ 键的吸收 $\left(960\right.$ 和 $\left.956 \mathrm{~cm}^{-1}\right)$. 酸处理后于 960 $\mathrm{cm}^{-1}$ 处的吸收说明有 $\mathrm{Si}-\mathrm{OH}$ 空位生成 ${ }^{[29]}$. 而二次合成的 $\mathrm{Sn}-\mathrm{B}$ 沸石中 $960 \mathrm{~cm}^{-1}$ 波数的吸收归属于与 $\mathrm{Sn}$ 相连组成四 配位 $\mathrm{Si}-\mathrm{O}-\mathrm{Sn}$ 键的 $\mathrm{Si}-\mathrm{O}$ 键伸缩振动 ${ }^{[30]}$. 另外, Al-B和B-B 中分别位于 1085 和 $1095 \mathrm{~cm}^{-1}$ 处的吸收在酸处理后向高 波数移动, 也说明 $\mathrm{Al}$ 和 $\mathrm{B}$ 从骨架中脱除 ${ }^{[31]}$.

\section{2. 葡萄糖异构化制果糖}

\subsection{1. 反应温度和时间的影响}

Sn- $\beta$ 沸石已经被证明是葡萄糖异构为果糖的一种 有效的多相催化剂, 这为碳水化合物生物精制提供了机 会 ${ }^{[16]}$. 基于此, 我们考察了所制备的 $\mathrm{Sn}-\beta$ 沸石在葡萄糖 异构为果糖反应中的性能. 图4 是反应温度和时间对 Sn-Al- $\beta$ 沸石上葡萄糖异构化反应的影响. 反应在 $353 \mathrm{~K}$ 进行 $2 \mathrm{~h}$, 果糖收率只有 $10 \%$; 将反应温度升高到 $393 \mathrm{~K}$, 反应 $1 \mathrm{~h}$ 后果糖收率达到约 $40 \%$. 葡萄糖异构为果糖是
轻微吸热反应 ${ }^{[16]}$, 所以升高温度有利于葡萄糖转化率 和果糖收率的提高. 当温度提高到 $403 \mathrm{~K}$, 反应 $0.5 \mathrm{~h}$ 后 果糖收率即达到最大值. 继续延长反应时间, 果糖收率 稍有下降, 可能是高温下果糖转化为其他水解副产物和 腐殖质等 ${ }^{[32]}$. 为得到较高的葡萄糖转化率和果糖收率, 于 $393 \mathrm{~K} 反$ 应 $2 \mathrm{~h}$ 比较合适.

\subsection{2. 催化剂用量的影响}

图5是催化剂用量对 Sn-Al- $\beta$ 沸石上葡萄糖异构化的 影响. 空白试验(393 K, 2 h) 表明, 在没有催化剂的情况 下葡萄糖在水相中不会异构化为果糖. 当催化剂用量为 $10 \mathrm{mg}$ 时, 葡萄糖转化率和果糖收率分别为约 $40 \%$ 和 $30 \%$; 至 $20 \mathrm{mg}$ 时两者分别升至 $50 \%$ 和 $40 \%$. 继续提高催 化剂用量, 尽管葡萄糖转化率上升, 但果糖收率降低. 这可能是由于过量的催化剂提供的过量 L酸中心, 导致 了更多的副反应.

由图1和图2可知, 二次合成样品较水热合成样品中 含有更多的非骨架小颗粒和大颗粒 $\mathrm{SnO}_{2}$. 在水为溶剂, 于 $393 \mathrm{~K}$ 反应 $2 \mathrm{~h}$ 时, Sn- $\beta, \mathrm{Sn}-\mathrm{Al}-\beta$ 和 Sn-B- $\beta$ 上的葡萄糖转 化率分别为 $\sim 66 \%, \sim 66 \%$ 和 $\sim 65 \%$, 对应的果糖产率分 别为 $46 \%, \sim 43 \%$ 和 $43 \%$. 这表明非骨架 $\mathrm{Sn}$ 物种对葡萄 糖异构没有不利影响. 一般认为, 只有骨架 $\mathrm{Sn}$ 能够提供 催化葡萄糖异构的活性中心 ${ }^{[21,23]}$, 所以推测含 $\mathrm{Sn}$ 样品中 的骨架 $\mathrm{Sn}$ 含量大致相当.

\subsection{3. 溶剂的影响}

三种含有不同阴离子的离子液体1-叔丁基-3-甲基 咪唑氯([bmim]Cl)，1-乙基-3-甲基咪唑溴([emim]Br), 和 1-叔丁基-3-甲基咪唑六氟磷酸([bmim $] \mathrm{PF}_{6}$ )和三种强极 性有机溶剂 $N, N$-二甲基甲酰胺(DMF), N,N-二甲基乙酰 胺(DMA)和二甲基亚砜(DMSO)用于比较溶剂对葡萄糖 异构反应性能的影响, 结果见图6. 葡萄糖在以上溶剂 中均可完全溶解. 以离子液体为溶剂时, 虽然有大量葡 萄糖转化, 但没有果糖生成. 鉴于可能的葡萄糖异构化 机理 ${ }^{[33]}$, 离子液体可能阻碍了葡萄糖分子与 $\mathrm{Sn}-\beta$ 的接触 进而反应. 如图7所示, 果糖收率随着溶剂中离子液体 含量的增加而持续降低. 而在有机溶剂DMSO, DMF和 DMA中果糖的收率分别为 $4.9 \%, 16.2 \%$ 和 $29.7 \%$, 可能 是因为这些有机溶剂作为 L 碱在 $S n-A 1-\beta$ 的 L 酸中心上发 生与葡萄糖分子的竞争吸附. 文献也有报道, 有机溶剂 中沸石 $\mathrm{L}$ 酸中心会与反应物的羟基/羰基发生强相互作 用 $^{[34]}$.

\subsection{4. 卤盐添加物的影响}

离子液体，比如 $[\mathrm{BMIM}] \mathrm{Cl}$ ，极大抑制葡萄糖异构 
的原因有可能在于其中的阴离子. 我们在相同的反应条 件下考察了一系列卤化钠对反应性能的影响，结果如表 2. 可以看出, 卤化钠的添加不利于葡萄糖异构的进行. 其中 $\mathrm{NaI}$ 的加入对反应的影响较小; 当 $\mathrm{NaCl}$ 和 $\mathrm{NaBr}$ 用量 从 $10 \mathrm{mg}$ 增加到 $50 \mathrm{mg}$, 果糖收率从约 $33 \%$ 降低到约 $25 \%$. 这说明 $\mathrm{Cl}^{-}$和 $\mathrm{Br}^{-}$可能与 $\mathrm{Sn}$ 活性中心结合，阻止了葡萄 糖异构化, 进而导致了果糖收率降低. 而仅仅 $10 \mathrm{mg}$ $\mathrm{NaF}$ 的加入，就使得果糖收率从约 $43 \%$ 降低到约 $20 \%$. 有报道指出, 卤化钠会增强水溶液中葡萄糖的盐析效

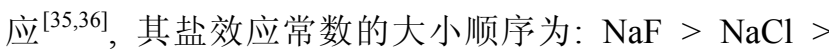
$\mathrm{NaBr}$. 可见，果糖收率降低值的变化趋势与卤化钠的盐 析效应强度一致. 因此，在没有卤化钠添加的情况下， Sn-Al- $\beta$ 在水中表现出很高的葡萄糖异构化能力, 这可 能解释了在离子液体 $[\mathrm{BMIM}] \mathrm{Cl}$ 中葡萄糖异构化性能降 低的原因.

\subsection{5. 催化剂重复使用性}

以 $\mathrm{Sn}-\mathrm{Al}-\beta$ 为催化剂，考察了其在葡萄糖异构化反 应中的重复使用性能. 发现反应过程中有积炭产生，导 致果糖收率从第一次使用的 $43.2 \%$ 降低到第二次的 $39.8 \%$ (催化剂不再生, 只过滤分离并在393 K干燥后重
复使用). 为避免积炭的影响, 催化剂每次使用后在 813 $\mathrm{K}$ 焙烧4 h进行再生，然后用于反应，重复4次，结果见表 3 (反应放大 20 倍后, 可能是因为搅拌效率的问题, 葡萄 糖转化率和果糖收率均稍有降低). 可以看出, 再生催 化剂性能和新鲜催化剂的差别不大，说明二次合成的 Sn-B沸石可以有效从反应体系分离和重复使用.

\section{4. 结论}

快捷合成Sn- $\beta$ 的二次合成法包含杂原子脱除和与 $\mathrm{SnCl}_{4}$ 同晶取代反应两步，它可将合成时间从水热法的 约 $40 \mathrm{~d}$ 降至 $1 \mathrm{~d}$ 以下, 且无需使用有毒的HF. 与水热法相 比，二次合成法Sn- $\beta$ 沸石具有更高的 $\mathrm{Sn}$ 含量(包含骨架 $\mathrm{Sn}$ 和非骨架 $\mathrm{Sn}$ ), 且催化葡萄糖异构性能相当, 在水溶 液中于 $393 \mathrm{~K} 反$ 应 $2 \mathrm{~h}$, 葡萄糖转化率和果糖最大收率分 别达到约 $66 \%$ 和 $43 \%$. 溶剂对反应性能的影响很大：其 中水是最好的溶剂; 离子液体阻碍 $\mathrm{S} n-\beta$ 上葡萄糖异构化 反应; 在DMSO, DMF和DMA中, 果糖收率较低, 可能 是因为这些有机溶剂作为一种 $\mathrm{L}$ 碱, 与催化剂的 $\mathrm{L}$ 酸活 性中心上发生竞争吸附. 另外, 催化剂具有很好的重复 使用性能，有望应用于生物质转化领域中. 